RESIDENT

\& FELLOW

SECTION

Section Editor

Mitchell S.V. Elkind,

MD, MS

Patricio S. Espinosa, $\mathrm{MD}, \mathrm{MPH}$

Address correspondence and reprint requests to Dr. Patricio S. Espinosa, Department of Neurology, Kentucky Clinic (Room L-445), Lexington, KY 40536-0284

psespi2@uky.edu

\section{Teaching NeuroImage: One-and-a-half syndrome}

回的

A 28-year-old right-handed man with no medical history presented with sudden onset of double vision. The patient stated that the double vision was worse when looking to the right, and he was not able to move his eyes to the left. On examination, the patient had a conjugate gaze palsy to the left and impaired adduction in the left eye (video), which persisted during saccades, pursuit, and oculocephalic movements. Vertical eye movements were normal, and no ocular bobbing was observed. MRI showed multiple periventricular white matter lesions and a central lesion in the pontine tegmentum (figure).

One-and-a-half syndrome is a gaze abnormality characterized by a conjugate horizontal gaze palsy in one direction plus an internuclear ophthalmoplegia in the other. ${ }^{1}$ The syndrome is usually caused by a single unilateral lesion of the paramedian pontine reticular formation or the abducens nucleus on one side (causing the conjugate gaze palsy to the side of the lesion), with interruption of internuclear fibers of the ipsilateral medial longitudinal fasciculus after it has crossed the midline from its site of origin in the contralateral abducens nucleus (causing failure of adduction of the ipsilateral eye). ${ }^{1}$ One-and-a-half syndrome is most often caused by multiple sclerosis (MS), brain stem stroke, brain stem tumors, and arteriovenous malformations. ${ }^{1}$ This patient was diagnosed with MS in accordance with the McDonald Criteria for MS. ${ }^{2}$

\section{REFERENCES}

1. Wall M, Wray SH. The one-and-a-half syndrome: a unilateral disorder of the pontine tegmentum-a study of 20 cases and review of the literature. Neurology 1983;33:971-978.

2. Polman CH, Reingold SC, Edan G, et al. Diagnostic criteria for multiple sclerosis: 2005 revisions to the “McDonald Criteria.” Ann Neurol 2005;58:840-846.

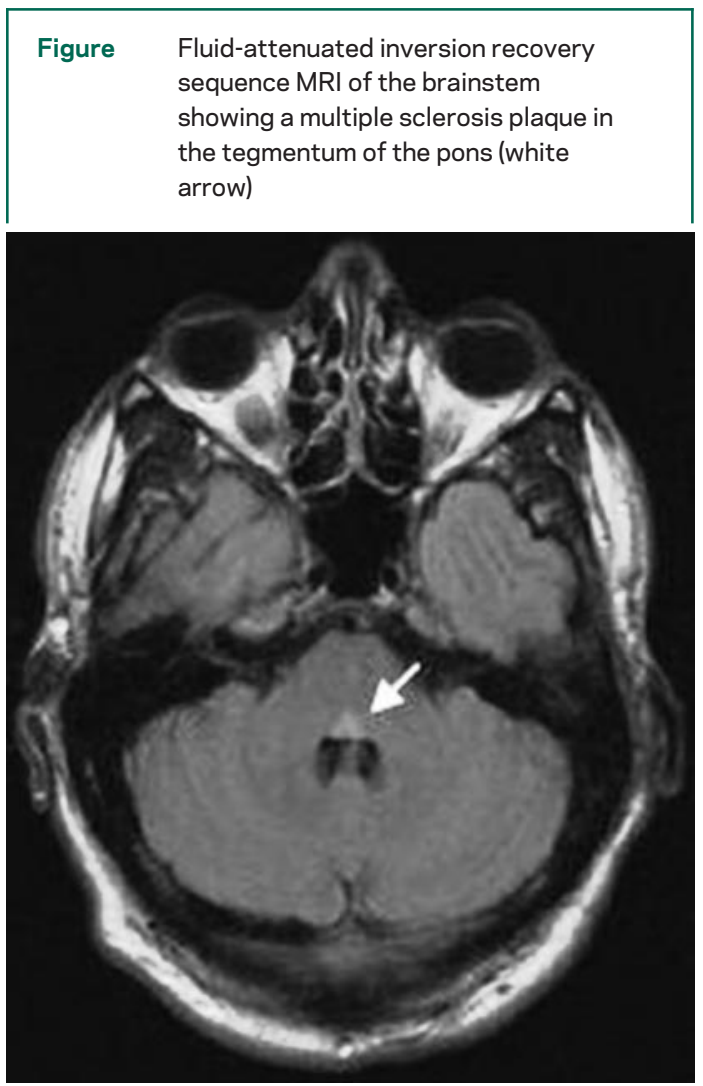




\section{Neurology}

\section{Teaching NeuroImage: One-and-a-half syndrome}

Patricio S. Espinosa

Neurology 2008;70; 20

DOI 10.1212/01.wnl.0000286933.31574.f4

This information is current as of January 28, 2008

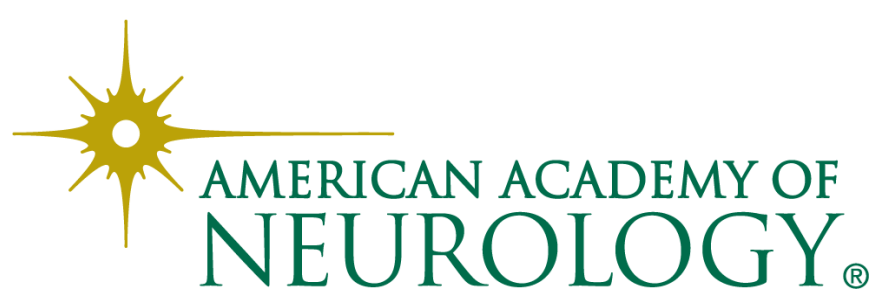




\section{Updated Information \&} Services

\section{Supplementary Material}

\section{References}

Subspecialty Collections

\section{Permissions \& Licensing}

Reprints including high resolution figures, can be found at: http://n.neurology.org/content/70/5/e20.full

Supplementary material can be found at: http://n.neurology.org/content/suppl/2008/01/24/70.5.e20.DC1

This article cites 2 articles, 1 of which you can access for free at: http://n.neurology.org/content/70/5/e20.full\#ref-list-1

This article, along with others on similar topics, appears in the following collection(s):

All Demyelinating disease (CNS)

http://n.neurology.org/cgi/collection/all_demyelinating_disease_cns All Education

http://n.neurology.org/cgi/collection/all_education

Autoimmune diseases

http://n.neurology.org/cgi/collection/autoimmune_diseases

Clinical neurology examination

http://n.neurology.org/cgi/collection/clinical_neurology_examination

Diplopia (double vision)

http://n.neurology.org/cgi/collection/diplopia_double_vision

MRI

http://n.neurology.org/cgi/collection/mri

Multiple sclerosis

http://n.neurology.org/cgi/collection/multiple_sclerosis

Ocular motility

http://n.neurology.org/cgi/collection/ocular_motility

Information about reproducing this article in parts (figures,tables) or in its entirety can be found online at:

http://www.neurology.org/about/about_the_journal\#permissions

Information about ordering reprints can be found online:

http://n.neurology.org/subscribers/advertise

Neurology ${ }^{\circledR}$ is the official journal of the American Academy of Neurology. Published continuously since 1951, it is now a weekly with 48 issues per year. Copyright . All rights reserved. Print ISSN: 0028-3878. Online ISSN: 1526-632X.

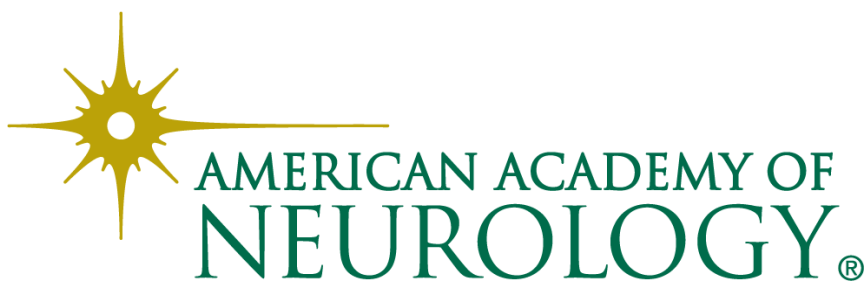

